\title{
Activation of Nrf2 by Ischemic Preconditioning and Sulforaphane in Renal Ischemia/Reperfusion Injury: a Comparative Experimental Study
}

\author{
A. A. SHOKEIR ${ }^{1}$, N. BARAKAT ${ }^{1}$, A. M. HUSSEIN ${ }^{2}$, A. AWADALLA ${ }^{1}$, A. M. HARRAZ ${ }^{1}$, \\ S. KHATER ${ }^{1}$, K. HEMMAID ${ }^{3}$, A. I. KAMAL ${ }^{1}$ \\ ${ }^{1}$ Urology and Nephrology Center, Mansoura University, Mansoura, Egypt, ${ }^{2}$ Physiology \\ Department, Faculty of Medicine, Mansoura University, Mansoura, Egypt, ${ }^{3}$ Faculty of Science, \\ Zagazig University, Zagazig, Egypt
}

Received May 26, 2014

Accepted August 29, 2014

On-line December 22, 2014

\section{Summary}

Objectives of the study were to investigate impact of ischemic preconditioning (Ipre) and sulforaphane (SFN) and combination of them on nuclear factor 2 erythroid related factor 2 (Nrf2) gene and its dependent genes, heme oxygenase-1 (HO1) and NADPHquinone oxidoreductase1 (NQO-1) and inflammatory cytokines TNF- $a$, IL1 $\beta$, and intercellular adhesion molecule-1 (ICAM1) and caspase- 3 in renal ischemia/reperfusion (I/R) injury. Ninety male Sprague Dawely rats were classified into 5 groups (each consists of 18 rats): sham, control, Ipre, sulforaphane and Sulfo+Ipre. Each group was subdivided into 3 subgroups each containing 6 rats according to time of harvesting kidney and taking blood samples; $24 \mathrm{~h}, 48 \mathrm{~h}$, and 7 days subgroups. Renal functions including serum creatinine, BUN were measured at basal conditions and by the end of experiment. Expression of Nrf2, HO- 1 , NQO- 1 , TNF-a, IL- $1 \beta$, and ICAM- 1 was measured by real time PCR in kidney tissues by the end of experiment. Also, immunohistochemical localization of caspase-3 and chemical assay of malondialdehyde (MDA), GSH and SOD activity were measured in kidney tissues. Both Ipre and SFN improved kidney functions, enhanced the expression of Nrf2, HO-1, and NQO-1, attenuated the expression of inflammatory (TNF-a, IL-1, and ICAM-1) and apoptotic (caspase-3) markers. However, the effect of sulforaphane was more powerful than Ipre. Also, a combination of them caused more improvement in antioxidant genes expression and more attenuation in inflammatory genes but not caspase-3 than each one did separately. Sulforaphane showed more powerful effect in renoprotection against I/R injury than Ipre as well as there might be a synergism between them at the molecular but not at the function level.

\section{Key words}

Nrf2 • HO-1 • NQO-1 • Preconditioning • Sulforaphane • Oxidative stress markers • Cytokines $\bullet$ Ischemia/reperfusion

\section{Corresponding author}

A. M. Hussein, Physiology Department, Faculty of Medicine, Mansoura University, Mansoura, Egypt. Fax: +20502263717. E-mail: zizomenna28@yahoo.com; menhag@mans.edu.eg

\section{Introduction}

Renal warm ischemia/reperfusion (I/R) injury is a common problem in many clinical situations such as kidney transplantation and renal vascular surgery (Saito and Miyagawa 2000, Weight et al. 2001). It is complex inflammatory condition, including ATP depletion, accumulation of intracellular $\mathrm{Ca}^{2+}$ and reactive oxygen species (ROS), pro-inflammatory cytokine production and apoptotic pathway activation. During kidney transplantation, renal $(\mathrm{I} / \mathrm{R})$ injury is a common cause of renal cell death, renal failure, delayed graft function (Pirsch et al. 1996) and renal graft rejection (Carpenter 1995). So, it is essential to protect the kidney against $\mathrm{I} / \mathrm{R}$ injury by exogenous agents or by enhancing the endogenous ability of the kidney cells to withstand this injury. 
During evolution, cells have developed inducible defense systems against harmful the toxic and hypoxic insults. Several transcription factors are involved in boosting the cell's defenses. One of them is the transcription nuclear factor-erythroid 2-related factor 2 (Nrf2) which was identified as a regulator of expression of the beta-globin genes (Moi et al. 1994). Soon it was discovered that $\mathrm{Nrf2}$ is a positive regulator of the human Antioxidant Response Element (ARE) that drives expression of antioxidant enzymes such as $\mathrm{NAD}(\mathrm{P}) \mathrm{H}$ :quinone oxidoreductase 1 (NQO-1) (Venugopal and Jaiswal 1998). Later on, it was found that Nrf2 plays a crucial role in the cellular protection against oxidative stress. Nrf2 is referred to as the "master regulator" of the antioxidant response due to the fact that it modulates the expression of several genes including phase 2 and antioxidant enzymes playing an important role in detoxification of reactive oxygen species (ROS) and electrophilic species, including heme oxygenase-1, $\mathrm{NAD}(\mathrm{P}) \mathrm{H}$ :quinone oxidoreductase, glutathione-Stransferase, gamma-glutamyl cysteine ligase, glutathione reductase, etc. Recent studies demonstrate that dysfunction of Nrf2-driven pathways impairs cellular redox state thus oxidative stress (reviewed in Silva-Islas et al. 2012). So, up regulation of the ARE-gene battery has a significant impact on the ability of the cell to withstand and survive sustained oxidative insults.

Recent studies by our group demonstrated the protective action of ischemic preconditioning (Ipre) against renal $\mathrm{I} / \mathrm{R}$ injury (Shokeir et al. 2012) and activation of Nrf2 system and its dependent genes by ischemic preconditioning in renal $\mathrm{I} / \mathrm{R}$ injury rat model (Shokeir et al. 2014). Also, it was reported that, sulforaphane, a natural dietary isothiocyanate present in cruciferous vegetables as broccoli, brussel sprouts, cauliflower, cabbage, is an excellent inducer for Nrf2 gene and its pathway (Hong et al. 2005). Several studies have shown the protective properties of sulforaphane against ischemia/reperfusion damage in brain (Zhao et al. 2006, Ping et al. 2010, Chen et al. 2011) and kidney (Yoon et al. 2008). However, which is more powerful in activation of Nrf2, sulforaphane or Ipre is not studied before. Moreover, we hypothesized that a combination of Ipre and sulforaphane could have a synergistic effect on activation Nrf2, hence could confer more protection of kidney against $\mathrm{I} / \mathrm{R}$ injury. So, this study was designed to investigate the combined effects of Ipre and sulforaphane on Nrf2 activation as well as to compare their effects.

\section{Materials and Methods}

\section{Experimental animals and ethical considerations}

The material of this work included 90 male Sprague Dawely rats weighing 200-250 g aging 4-6 months which were bred in the animal research facility in the Urology \& Nephrology Center at Mansoura, Egypt. Experiments were performed according to the Guide for the Care and Use of Laboratory Animals (Institute for Laboratory Animal Research, National Research Council, Washington, DC, National Academy Press, no. 85-23, revised 1996). All protocols were approved by our ethical committee of Mansoura, Faculty of Medicine.

\section{Study design}

Animals were randomly divided into 5 groups; 1) Sham group (18 rats): rats were subjected to right nephrectomy, exposure of left renal pedicle with no ischemia, 2) Control group (18 rats): rats were subjected to right nephrectomy and left renal ischemia for $45 \mathrm{~min}$ (definitive ischemia), 3) Ischemic preconditioning (Ipre) group (18 rats): like control group, but three cycles of 2 min ischemia followed by 5 -min reperfusion period to $\mathrm{I} / \mathrm{R}$ were done before the definitive 45 -min ischemia (Ambros et al. 2007), 4) Sulforaphane group (18 rats): like control group, but sulforaphane (500 $\mu \mathrm{g} /$ body weight $\mathrm{kg}$, i.v.) was given to the rats $1 \mathrm{~h}$ before clamping of renal pedicle and 5) Ipre + Sulforaphane group (18 rats): like control group, but Ipre was done plus sulforaphane was given to the rats.

The rats in each group were subdivided into 3 subgroups (each was 6 rats), $24 \mathrm{~h}, 48 \mathrm{~h}$ and 7 days subgroups, according to the time of harvesting of kidney tissues. Blood samples were taken from each subgroup at the end of the experiment, i.e. at $24 \mathrm{~h}, 48 \mathrm{~h}$ and 7 days after surgery. Blood $(1 \mathrm{ml})$ was obtained from the ophthalmic venous plexus using a fine-walled Pasteur pipette. The rat was anesthetized using halothane inhalation and the pipette was positioned at the inner corner of the eye beside the eyeball, and pushed gently but firmly along the side of the orbit to the ophthalmic venous plexus. Blood was centrifuged and serum stored at $20^{\circ} \mathrm{C}$ for measurement of serum creatinine and blood urea nitrogen (BUN) later on.

By the end of experiment in each subgroup, the left kidney was harvested and divided into 2 halves, one half was placed in formalin $10 \%$ for immunohischemical localization of Nrf2 and caspase-3, while the remaining half was stored at $-80{ }^{\circ} \mathrm{C}$ for real time PCR assay of inflammatory markers, TNF- $\alpha$, IL- $1 \beta$, and ICAM-1, Nrf2 
gene and antioxidant genes HO-1 and NQO-1.

\section{Assessment of renal functions}

Kidney functions were assessed by measurement of serum creatinine, and serum BUN at basal conditions and end of experiment. The concentrations of creatinine and BUN in serum were measured using an auto-analyser (CX 7; Beckman, Foster City, CA, USA).

Chemical assay of oxidative stress markers (MDA, SOD and GSH)

Kidney tissue was perfused with a PBS (phosphate buffered saline) solution, $\mathrm{pH} 7.4$ containing $0.16 \mathrm{mg} / \mathrm{ml}$ heparin to remove any red blood cells and clots. Then, kidney was weighed, minced, homogenized in $5-10 \mathrm{ml}$ cold buffer (i.e. $50 \mathrm{mM}$ potassium phosphate, pH 7.5. 1 mM EDTA). Homogenates were centrifuged at $10000 \mathrm{x} \mathrm{g}$ for $15 \mathrm{~min}$ at $4{ }^{\circ} \mathrm{C}$ and the supernatant was kept at $-80^{\circ} \mathrm{C}$ till used for analysis of lipid peroxides (malondialdehyde, MDA), superoxide dismutase (SOD), and reduced glutathione (GSH). MDA, SOD, and GSH were measured by using colorimetric kit (Bio-Diagnostics, Dokki, Giza, Egypt) according to manufacturer's instructions.

Real time PCR for TNF- $\alpha, I L-1 \beta$ and intercellular adhesion molecule-1 (ICAM-1), Nrf2, HO-1 and NQO-1 genes

RNA extraction and $c D N A$ synthesis

According to the manufacturer's instructions, total RNA from kidney tissue specimens was isolated by disruption of $50-100 \mathrm{mg}$ tissues in $1 \mathrm{ml}$ of Trizol (Invitrogen Corporation, Grand Island, NY, USA). RNA was quantified spectrophotometrically, and its quality was determined by agarose gel electrophoresis and ethidium bromide staining. Only samples that were not degraded and showed clear $18 \mathrm{~S}$ and $28 \mathrm{~S}$ bands under ultraviolet light were used for real-time RT-PCR. Reverse transcription was done using $1 \mu \mathrm{g}$ total RNA and a cDNA kit (high-capacity cDNA archive kit). The primer sequences for tested genes were TNF $\alpha$ (295 bp) forward: 5'-TACTGAACTTCGGGGTGATTGGTCC-3', reverse: 5'-CAGCCTTGTCCCTTGAAGAGAACC-3', ICAM-1 (409 bp) 5'-TGTTTCCTGCCTCTGAAGC-3', Nuclear erythroid-related factor 2 (Nrf2) (109 bp), forward: 5'-GCTATTTTCCATTCCCGAGTTAC-3', reverse: 5'-ATTGCTGTCCATCTCTGTCAG-3'. NAD (P) H: quinine oxidoreductase-1 (NQO-1) (197 bp), forward: 5'-CATCATTTGGGCAAGTCC-3', reverse: 5'-ACAG
CCGTGGCAGAACTA-3'. Heme oxidase-1 (HO-1) (102 bp), forward: 5'-CTTTCAGAAGGGTCAGGT GTC-3', reverse: 5'-TGCTTGTTTCGCTCTATCTCC-3'. IL-1 $\beta$ (131 bp), forward: 5'-TGTGATGTTCCCATT AGAC-3', reverse: 5'-AATACCACTTGTTGGCTTA-3'. GAPDH (140 bp) forward: 5'-TATCGGACGCCTGG TTAC-3', reverse: 5'-CTGTGCCGTTGAACTTGC-3'.

\section{Real time PCR reaction}

The reaction was performed in a total volume of $50 \mu \mathrm{l}$ containing $25 \mu \mathrm{l}$ from $1 \mathrm{x}$ TaqMan ${ }^{\circledR}$ Universal PCR with $2.5 \mu \mathrm{l}$ from 20x TaqMan ${ }^{\circledR}$ Gene Expression Assay Mix and $22.5 \mu \mathrm{l}$ of cDNA diluted in RNase-free water. The cycling parameters were as follows: initial denaturation at $95^{\circ} \mathrm{C}$ for $10 \mathrm{~min}$, followed by 40 cycles of denaturation $95{ }^{\circ} \mathrm{C}$ for $15 \mathrm{~s}$, annealing at $60^{\circ} \mathrm{C}$ for $1 \mathrm{~min}$, extension at $72{ }^{\circ} \mathrm{C}$ for $1 \mathrm{~min}$. Data analysis was carried out using ABI prism 7000 by equation $2-^{\Delta \Delta}$ ct (Livak and Schmittgen 2001).

\section{Immunohistochemical examination of caspase-3}

Explanted kidneys were bisected along the long axis and were fixed in $10 \%$ formalin solution for $24 \mathrm{~h}$. After automated dehydration through a graded alcohol series, transverse kidney slices were embedded in paraffin, sectioned at $4 \mu \mathrm{m}$, and stained with hematoxylin and eosin. For immunohistochemistry to assess the apoptotic index, $3-\mu \mathrm{m}$-thick sections were prepared on charged slides and deparaffinized. All sections were incubated for $30 \mathrm{~min}$ with $0.3 \%$ hydrogen peroxide in methanol and microwave-heated in $10 \mathrm{mM}$ citrate buffer, pH 6.0, for 10-20 min. Subsequently, an indirect immunoperoxidase technique was applied, using monoclonal antibodies for anti-caspase-3 (Abcam, catalogue number: ab79123). Indirect immunoperoxidase was performed using ImmunoPure UltraSensitive ABC Peroxidase (Thermo Scientific, catalogue number: 32052) with (DAB) as chromogen. Proper positive and negative controls were performed. Tonsils were used as positive control for caspase-3. In negative control, sections were stained without the addition of a primary antibody. The apoptotic index of caspase- 3 was assessed with a standard point-counting method for the percentage of labelled tubular cells (excluding necrotic tubules) in nonoverlapping, randomly selected 10 high power fields of each slide (Duan et al. 2003).

\section{Statistical analysis}

Statistical analysis was done by using SPSS 
Table 1. Effects of Iprecond and sulforaphane and combination of them on kidney functions (serum creatinine and BUN) at $24 \mathrm{~h}, 48 \mathrm{~h}$ and 7 days after ischemia.

\begin{tabular}{|c|c|c|c|c|}
\hline Parameter & Group & $\begin{array}{c}24 \text { h group } \\
(n=10)\end{array}$ & $\begin{array}{c}48 \text { h group } \\
(n=10)\end{array}$ & $\begin{array}{l}7 \text { days } \\
(n=10)\end{array}$ \\
\hline \multirow{5}{*}{$\begin{array}{l}\text { Serum creatinine } \\
(\mathrm{mg} / \mathrm{dl})\end{array}$} & Sham & $0.60 \pm 0.05$ & $0.55 \pm 0.11$ & $0.51 \pm 0.10$ \\
\hline & $I / R$ & $2.18 \pm 0.22^{*}$ & $2.75 \pm 0.17^{*}$ & $1.61 \pm 0.16^{*}$ \\
\hline & Iprecond & $\begin{array}{c}1.12 \pm 0.17^{* \#} \\
(-48.62 \%)\end{array}$ & $\begin{array}{c}1.05 \pm 0.09^{* \#} \\
(-61.82 \%)\end{array}$ & $\begin{array}{c}1.00 \pm 0.12^{*} \# \\
(-37.89 \%)\end{array}$ \\
\hline & Sulforaphane & $\begin{array}{c}1.06 \pm 0.21 * \# \\
(-51.38 \%)\end{array}$ & $\begin{array}{c}0.88 \pm 0.13^{* \# \$} \\
(-68.00 \%)\end{array}$ & $\begin{array}{c}0.77 \pm 0.17^{* \# \$} \\
(-52.17 \%)\end{array}$ \\
\hline & Ipre + Sulfo & $\begin{array}{c}1.01 \pm 0.03^{* \#} \\
(-53.67 \%)\end{array}$ & $\begin{array}{c}0.75 \pm 0.02 * \# \$ \S \\
\quad(-72.72 \%)\end{array}$ & $\begin{array}{c}0.80 \pm 0.17 * \# \$ \\
(-50.31 \%)\end{array}$ \\
\hline \multirow{5}{*}{$\begin{array}{l}\text { Serum BUN } \\
(\mathrm{mg} / \mathrm{dl})\end{array}$} & Sham & $25.74 \pm 3.48$ & $25.02 \pm 3.31$ & $25.46 \pm 2.70$ \\
\hline & $I / R$ & $76.71 \pm 3.40^{*}$ & $61.03 \pm 2.90^{*}$ & $45.73 \pm 4.11^{*}$ \\
\hline & Iprecond & $\begin{array}{c}40.60 \pm 2.49^{*} \# \\
(-47.07 \%)\end{array}$ & $\begin{array}{c}36.09 \pm 1.53 * \# \\
(-40.86 \%)\end{array}$ & $\begin{array}{c}31.20 \pm 1.29^{*} \# \\
(-31.77 \%)\end{array}$ \\
\hline & Sulforaphane & $\begin{array}{c}36.60 \pm 3.16^{*} \# \$ \\
(-52.29 \%)\end{array}$ & $\begin{array}{c}29.10 \pm 4.77^{* \# \$} \\
(-52.32 \%)\end{array}$ & $\begin{array}{c}28.90 \pm 3.24 * \# \$ \\
(-36.80 \%)\end{array}$ \\
\hline & Ipre + Sulfo & $\begin{array}{c}34.16 \pm 2.97 * \# \$ \\
(-55.47 \%)\end{array}$ & $\begin{array}{c}28.10 \pm 5.02 * \# \$ \\
(-53.95 \%)\end{array}$ & $\begin{array}{c}29.52 \pm 2.31^{* \# \$} \\
\quad(-35.44 \%)\end{array}$ \\
\hline
\end{tabular}

All data were expressed as mean \pm SD. $\%=$ percent change from I/R group value of the same time interval, One way ANOVA test with post-hoc Scheffe's test (significant if $\mathrm{p} \leq 0.05$ ). * Significant vs sham group of the same time interval, \# significant vs I/R of the same time interval, \$ significant vs Iprecond group of the same time interval, § significant vs sulforaphane group of the same time interval.

computer program (version 10). One-way analysis of variance (ANOVA) was done to study test of significance within treated groups, within Scheffe's post-hoc test. Significance was considered when $\mathrm{p}$ values were less than 0.05 .

\section{Results}

Effects of Iprecond and sulforaphane and combination of them on kidney functions parameters (serum creatinine and $B U N)$

Compared to the sham group, I/R and all studied groups had significant increase in serum creatinine and BUN at all-time points of the study ( $24 \mathrm{~h}, 48 \mathrm{~h}$ and 7 days) $(p<0.05)$. Compared to the $I / R$ group, the Iprecond, sulforaphane and Ipre + sulfo groups showed significant improvement in serum creatinine and BUN at all-time points of the study $(p<0.05)$. Nevertheless, the percentage decrease in the Iprecond group was significantly less compared with sulforaphane group $(\mathrm{p}<0.05)$. Moreover, addition of Iprecond to sulforaphane did not cause more significant improvement in serum creatinine and BUN except serum creatinine at $48 \mathrm{~h}$ group (Table 1).
Effects of Iprecond and sulforaphane and combination of them on the expression of Nrf2, HO-1 and NQO-1

Real time PCR showed significant increase in the expression of Nrf2, HO-1 and NQO-1 in all studied groups (I/R, Ipre, sulforaphane and Ipre + sulfo) compared to sham group at all time periods of follow up $(\mathrm{p}<0.05)$. Compared to $\mathrm{I} / \mathrm{R}$ group, the other studied groups (Ipre, sulforaphane and Ipre + sulfo) showed significant increase in expression of these genes at all-time points of the study $(p<0.05)$. However, the degree of rise in the expression of these genes was significantly higher in sulforaphane group than Ipre. Moreover, the degree rise in the expression of $\mathrm{Nrf} 2$, HO-1 and NQO-1 was significantly high in Ipre + sulfo group compared to other treated groups at $48 \mathrm{~h}$ and NQO-1 at $2 \mathrm{~h}$ and $24 \mathrm{~h}(\mathrm{p}<0.05)$ (Fig. 1a,b and c).

Effects of Iprecond and sulforaphane and combination of them on the oxidative stress markers (MDA, SOD and GSH)

The results of oxidative stress markers showed significant increase in the levels of MDA and significant decrease in the activity of SOD in kidney tissues in all 
a

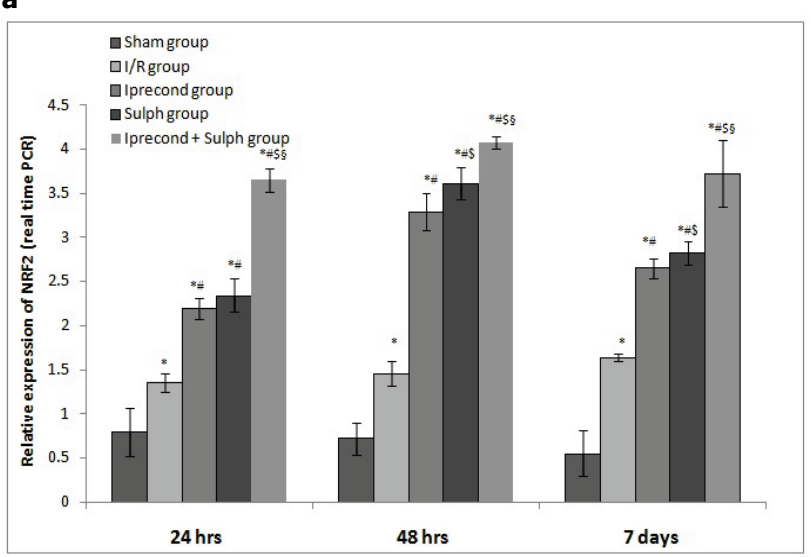

b

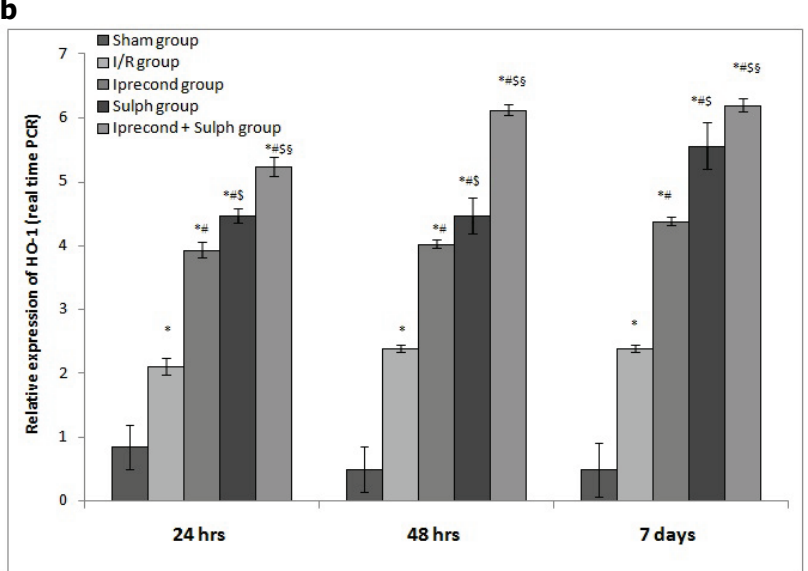

C

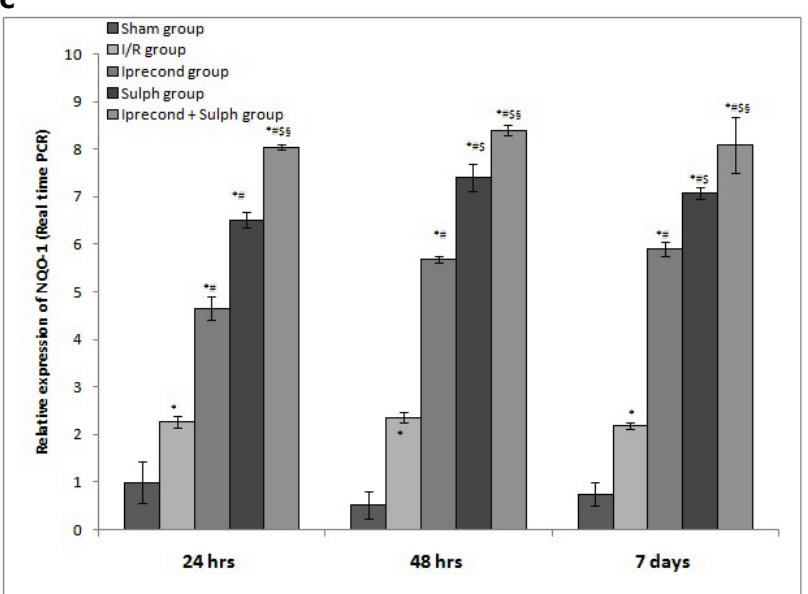

Fig. 1. Real time PCR expression of Nrf2 (a) gene and its dependent genes HO-1 (b) and NQO-1 (c) at $24 \mathrm{~h}, 48 \mathrm{~h}$ and 7 days after ischemia. * Significant vs sham group of the same time interval, \# significant vs I/R of the same time interval, \$ significant vs Iprecond group of the same time interval, $\S$ significant vs sulforaphane group of the same time interval.

studied groups (I/R, Ipre, sulforaphane and Ipre + sulfo) compared to sham group at all time periods of follow up $(p<0.05)$. However, GSH showed significant decrease in
$\mathrm{I} / \mathrm{R}$ group and increase in other groups compared to sham group $(\mathrm{p}<0.05)$. Compared to $\mathrm{I} / \mathrm{R}$ group, the other studied groups (Ipre, sulforaphane and Ipre + sulfo) showed significant increase in the levels of GSH and SOD activities with significant decrease in MDA levels in kidney tissues at all-time points of the study $(\mathrm{p}<0.05)$. However, the degree of improvement in these markers was significantly higher in sulforaphane group than Ipre. Moreover, the degree of improvement in the levels of GSH and SOD at all times of follow up and MDA at $24 \mathrm{~h}$ was significantly higher in Ipre + sulfo group than sulforaphane alone group $(\mathrm{p}<0.05)$. Unfortunately, MDA showed significant rise in its level in kidney tissues in Ipre + sulfo group than sulforaphane group alone at $48 \mathrm{~h}$ and 7 days $(\mathrm{p}<0.05)$ (Table 2$)$.

Effects of Iprecond and sulforaphane and combination of them on inflammatory cytokines (TNF- $\alpha, I L-1 \beta$, and ICAM-1)

Compared to the sham group, I/R, Ipre and sulforaphane groups showed significant increase in the expression of TNF- $\alpha$ and ICAM-1 in kidney tissues at all-time points of the study $(\mathrm{p}<0.05)$. On the other hand, IL-1 $\beta$ showed significant increase $\mathrm{I} / \mathrm{R}$ and Ipre groups only at early times ( $24 \mathrm{~h}$ and $48 \mathrm{~h}$ ) compared to sham group $(\mathrm{p}<0.05)$, without any significant difference between sham group and Ipre group at 7 days. Also, compared to $\mathrm{I} / \mathrm{R}$ group, Ipre, sulforaphane and Ipre + sulfo groups showed significant decrease in the expression of all of these markers at different times of follow up $(\mathrm{p}<0.05)$. Moreover, the degree in reduction of these markers was marked in sulforaphane and Ipre + sulfo groups compared to Ipre and in Ipre + sulfo group compared to sulforaphane $(\mathrm{p}<0.05)$ (Table 3 ).

Effects of Iprecond and sulforaphane and combination of them on expression of caspase-3

Kidneys from all studied groups (I/R, Ipre, sulforaphane and Ipre + sulfo) showed significant increase in the score of caspase-3 expression when compared with that from sham group $(\mathrm{p}<0.05)$. Compared to $\mathrm{I} / \mathrm{R}$, all other studied ( $/ \mathrm{R}$, Ipre, sulforaphane and Ipre + sulfo) groups showed significant reduction in the caspase-3 expression score $(\mathrm{p}<0.05)$. However, there were no statistical significant differences among all treated groups, i.e. Ipre, sulforaphane and Ipre + sulfo groups (Fig. 2a). Figures 2c-e are representative samples of immunostaining for caspase- 3 of different groups. 
Table 2. Effects of Iprecond and sulforaphane on oxidative stress markers (MDA, SOD and GSH) at $24 \mathrm{~h}, 48 \mathrm{~h}$ and 7 days after ischemia.

\begin{tabular}{|c|c|c|c|c|}
\hline & Group & $\begin{array}{c}\text { MDA } \\
\text { (nmol/g tissue) }\end{array}$ & $\begin{array}{c}\text { GSH } \\
\text { (mg/g tissue) }\end{array}$ & $\begin{array}{c}\text { SOD } \\
\text { (U/g tissue) }\end{array}$ \\
\hline \multirow{5}{*}{$24 h$} & Sham & $22.28 \pm 1.24$ & $214.28 \pm 8.56$ & $91.27 \pm 3.30$ \\
\hline & $I / R$ & $367.09 \pm 16.01^{*}$ & $114.30 \pm 14.06^{*}$ & $67.27 \pm 10.40^{*}$ \\
\hline & Iprecond & $152.06 \pm 12.97 * \#$ & $295.03 \pm 13.74 * \#$ & $79.15 \pm 4.84 * \#$ \\
\hline & Sulforaphane & $100.45 \pm 4.92 * \# \$$ & $370.59 \pm 15.50 * \# \$$ & $82.60 \pm 3.07 * \#$ \\
\hline & Ipre + Sulfo & $80.56 \pm 5.05^{*} \# \$ \S$ & $359.06 \pm 10.01^{*} \# \$ \S$ & $82.05 \pm 2.45^{*} \#$ \\
\hline \multirow{5}{*}{$48 h$} & Sham & $26.19 \pm 2.25$ & $204.29 \pm 14.13$ & $94.50 \pm 6.63$ \\
\hline & $I / R$ & $265.07 \pm 22.11 *$ & $32.26 \pm 8.47 *$ & $52.28 \pm 12.36^{*}$ \\
\hline & Iprecond & $79.04 \pm 5.26 * \#$ & $341.06 \pm 21.08^{*} \#$ & $77.39 \pm 2.06 * \#$ \\
\hline & Sulforaphane & $50.30 \pm 4.86^{* \# \$}$ & $380.67 \pm 7.10^{*} \# \$$ & $84.06 \pm 2.06^{* \# \$}$ \\
\hline & Ipre + Sulfo & $60.73 \pm 3.87 * \# \$ \S$ & $539.07 \pm 20.01 * \# \$ \S$ & $85.07 \pm 1.97 * \# \$$ \\
\hline \multirow{5}{*}{7 days } & Sham & $16.72 \pm 3.59$ & $225.50 \pm 11.90$ & $96.93 \pm 4.61$ \\
\hline & $I / R$ & $154.25 \pm 12.07 *$ & $132.04 \pm 12.15^{*}$ & $83.29 \pm 12.40^{*}$ \\
\hline & Iprecond & $42.01 \pm 7.11 * \#$ & $370.14 \pm 11.60^{* \#}$ & $81.05 \pm 2.44^{*}$ \\
\hline & Sulforaphane & $30.46 \pm 3.67 * \# \$$ & $421.60 \pm 5.06^{* \# \$}$ & $91.49 \pm 1.25 * \# \$$ \\
\hline & Ipre + Sulfo & $39.05 \pm 4.09 * \# \S$ & $452.07 \pm 5.39 * \# \$ \S$ & $92.06 \pm 3.06 * \# \$$ \\
\hline
\end{tabular}

All data were expressed as mean $\pm \mathrm{SD} . \%=$ percent change from I/R group value of the same time interval, One way ANOVA test with post-hoc Scheffe's test (significant if $\mathrm{p} \leq 0.05$ ).* Significant vs sham group of the same time interval, \# significant vs I/R of the same time interval, \$ significant vs Iprecond group of the same time interval, § significant vs sulforaphane group of the same time interval.

Table 3. Effects of Iprecond and sulforaphane and combination of them on the expression of inflammatory cytokines (TNF-a, ICAM-1 and $\mathrm{IL}-1 \beta)$ at $24 \mathrm{~h}, 48 \mathrm{~h}$ and 7 days after ischemia.

\begin{tabular}{|c|c|c|c|c|}
\hline & Group & TNF- $\alpha$ & ICAM-1 & IL-1及 \\
\hline \multirow{5}{*}{$24 h$} & Sham & $1.22 \pm 0.15$ & $0.87 \pm 0.14$ & $0.92 \pm 0.16$ \\
\hline & $I / R$ & $10.11 * \pm 0.41$ & $3.29 * \pm 0.46$ & $2.66^{*} \pm 0.15$ \\
\hline & Iprecond & $5.15 * \# \pm 0.23$ & $2.50 * \# \pm 0.10$ & $1.66 * \# \pm 0.13$ \\
\hline & Sulforaphane & $2.39 * \# \$ \pm 0.18$ & $1.99 * \# \$ \pm 0.11$ & $0.92 \# \$ \pm 0.04$ \\
\hline & Ipre + Sulfo & $0.50 * \# \$ \S \pm 0.07$ & $0.43^{*} \# \$ \S \pm 0.07$ & $0.37 * \# \$ \S \pm 0.04$ \\
\hline \multirow{5}{*}{$48 h$} & Sham & $1.41 \pm 0.23$ & $0.86 \pm 0.10$ & $0.83 \pm 0.11$ \\
\hline & $I / R$ & $11.96^{*} \pm 0.36$ & $4.25^{*} \pm 0.37$ & $3.19 * \pm 0.12$ \\
\hline & Iprecond & $4.12 * \# \pm 0.44$ & $2.06^{* \#} \pm 0.10$ & $1.92 * \# \pm 0.09$ \\
\hline & Sulforaphane & $1.71 \# \$ \pm 0.30$ & $1.46^{*} \pm 0.04$ & $0.53 \# \$ \pm 0.05$ \\
\hline & Ipre + Sulfo & $0.13^{*} \# \$ \S \pm 0.03$ & $0.09 * \# \$ \S \pm 0.01$ & $0.12 * \# \$ \S \pm 0.03$ \\
\hline \multirow{5}{*}{7 days } & Sham & $1.30 \pm 0.26$ & $0.78 \pm 0.13$ & $0.97 \pm 0.14$ \\
\hline & $I / R$ & $7.21 * \pm 0.53$ & $2.38^{*} \pm 0.37$ & $1.52 * \pm 0.39$ \\
\hline & Iprecond & $3.29 * \# \pm 0.24$ & $1.91 * \# \pm 0.05$ & $1.22 \# \pm 0.10$ \\
\hline & Sulforaphane & $1.03 \# \$ \pm 0.37$ & $1.64 * \# \pm 0.02$ & $0.98 \# \pm 0.12$ \\
\hline & Ipre + Sulfo & $0.13^{*} \# \$ \S \pm 0.03$ & $0.08^{*} \# \$ \S \pm 0.01$ & $0.07 * \# \$ \S \pm 0.01$ \\
\hline
\end{tabular}

All data were expressed as mean $\pm \mathrm{SD} . \%=$ percent change from I/R group value of the same time interval, One way ANOVA test with post-hoc Scheffe's test (significant if $\mathrm{p} \leq 0.05$ ). * Significant vs sham group of the same time interval, \# significant vs I/R of the same time interval, \$ significant vs Iprecond group of the same time interval, § significant vs sulforaphane group of the same time interval. 


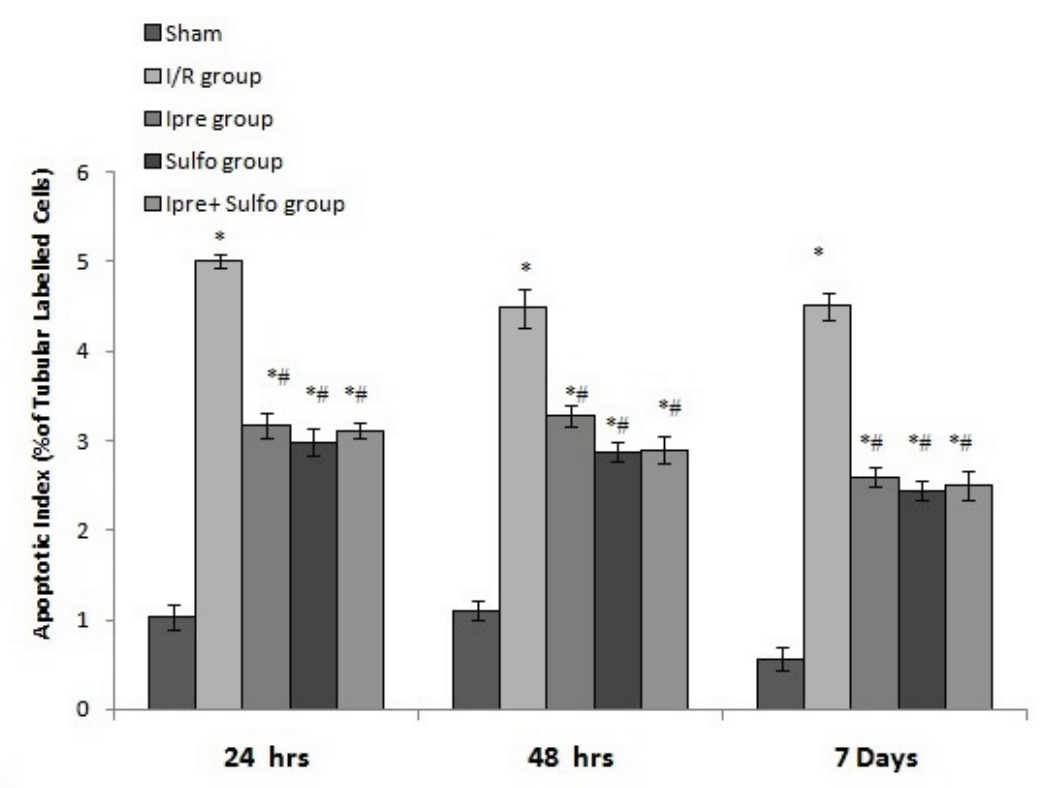

Fig. 2. Expression of caspase-3. (a) Scoring index for caspase- 3 expression at $24 \mathrm{~h}, 48 \mathrm{~h}$, and 7 days after ischemia, samples of kidney sections stained immunohistochemically using anti caspase-3 antibody from (b) control group with (c) Ipre group, (d) sulforaphane group and (e) Ipre + sulfo group (immunoperoxidase DAB X400). * Significant vs sham group of the same time interval, \# significant vs $I / R$ of the same time interval, \$ significant vs Iprecond group of the same time interval, § significant vs sulforaphane group of the same time interval.

a
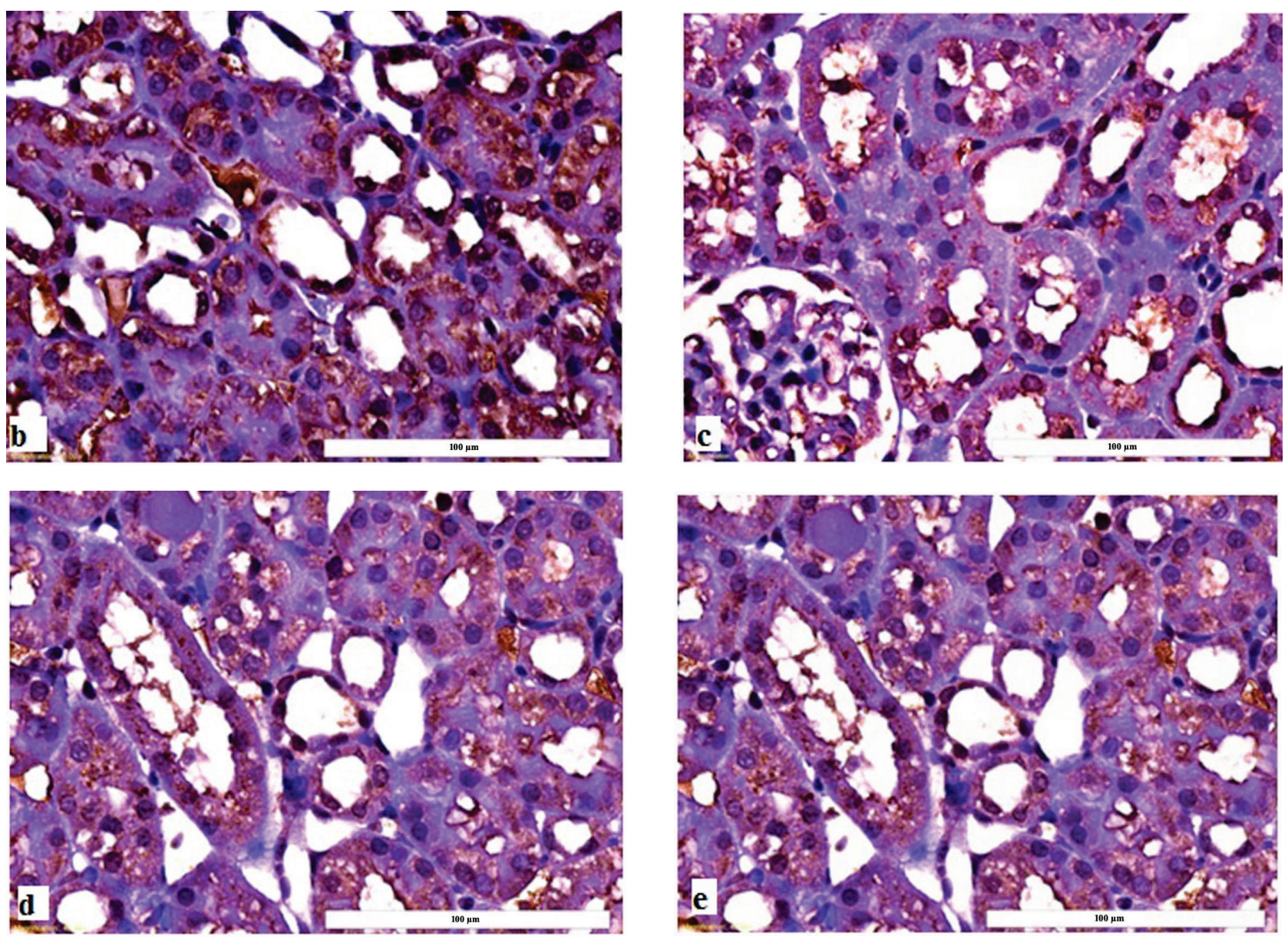

\section{Discussion}

The findings of the present study showed that a) using of Ipre or sulforaphane alone improved the kidney functions, enhanced the expression of $\mathrm{Nrf} 2$ factor and its dependent genes, improved redox state in kidney

tissues, attenuated the inflammatory process in kidney tissues and inhibited apoptosis in kidney tissues in case of $\mathrm{I} / \mathrm{R}$ injury, b) sulforaphane had a powerful effect in induction of Nrf2 and its dependent genes than Ipre, c) a combination of both Ipre and sulforaphane conferred more enhancement in the expression of antioxidant genes 
and more improvement in inflammatory state and antioxidants but not the apoptotic markers.

The first objective of this study was to examine the effect of Ipre and sulforaphane (single dose $500 \mathrm{ug} / \mathrm{kg}$ i.v. one hour before ischemia) alone or in combination on renal functions. The results of this study showed that using of Ipre or sulforaphane alone improved the kidney functions, and the effect of sulforaphane was more powerful than Ipre. These findings were in agreement with previous studies that reported the renoprotective for Ipre (Hernandez et al. 2008, Timsit et al. 2008, Shokeir et al. 2012, 2014) and sulforaphane (Yoon et al. 2008) against renal I/R injury. However, in the present study, a combination of Ipre and sulforaphane did not confer more improvement in kidney functions parameters (serum creatinine and BUN) than sulforaphane alone did at different times of follow up. Failure of synergistic effect between sulforaphane and Ipre could be explained on base of single low dose used for sulforaphane in the present study. In consistence with this hypothesis, Cui et al. (2012) found that administration of sulforaphane at a dose of $0.5 \mathrm{mg} / \mathrm{kg} /$ day in 5 days/week for 3 months significantly attenuated the progression of renal disease in a mice model of diabetic nephropathy and this effect disappeared after 6 months of sulforaphane treatment, while Zheng et al. (2011) found that administration sulforaphane in diabetic nephropathy at $12.5 \mathrm{mg} / \mathrm{kg} /$ day in 3 times/week caused improvement for 4 months.

Nrf2 transcription factor coordinates the regulation of over 200 genes in humans and animals $(\mathrm{Hu}$ et al. 2006, Zhu et al. 2008, Hayes and McMahon 2009), largely related to mechanisms of endogenous cellular defense and survival (Niture et al. 2010). Nrf2 has been variously described as "the master redox switch" (Surh et al. 2008), an "activator of cellular defense mechanisms" (Lee and Johnson 2004), and "a guardian of health span and gatekeeper of species longevity" (Lewis et al. 2010). As a mediator for amplification of the mammalian defense system against various stressors, Nrf2 sits at the interface between prior understanding of oxidative stress and the endogenous mechanisms used by cells to respond to oxidative stress. This factor can be induced by many factors such as sulforaphane and Ipre. So, the second objective of this study was to examine the effect of Ipre and sulforaphane and combination of them on induction of this factor and its dependent antioxidant genes. This study demonstrated both Ipre and sulforaphane had the power to enhance the induction of $\mathrm{Nrf} 2$ and its dependent genes HO-1 and NQO-1 and the effect of sulforaphane alone in induction of them was more powerful than Ipre alone. Similar studies reported this effect for sulforaphane and Ipre in induction of Nrf2 and HO-1 and NQO-1 genes (Yoon et al. 2008, Shokeir et al. 2014) in renal $\mathrm{I} / \mathrm{R}$ rat model. Moreover, this study demonstrated that a combination of both of Ipre and sulforaphane caused more enhancement of induction of these genes than each one did separately. However, this enhancement was not reflected on the renal functions. These findings suggested that the improvement in kidney functions is partly dependent on induction the antioxidant genes.

Also, this could be explained on base of low dose. Also, assessment of oxidative stress markers in kidney tissues showed significant reduction in MDA (marker of lipid peroxidation) with improvement in the antioxidants (SOD activity and GSH concentration) in Ipre and sulforaphane groups. And addition of Ipre to sulforaphane led to more improvement in the redox state than sulforaphane alone. A previous study done by our group reported similar results for Ipre on oxidative stress markers on kidney tissues in renal $\mathrm{I} / \mathrm{R}$ injury rat model (Shokeir et al. 2012). Also, recently Banday and Lokhandwala (2013) demonstrated that inhibition of oxidative stress and NF- $\kappa$ B activation through stimulation of a redox-sensitive transcription factor (nuclear factor E2-related factor 2- (Nrf2-) phase II antioxidant enzyme pathway) by sulforaphane maintained dopamine (D1) receptor functionality and prevents the development of hypertension.

Renal $\mathrm{I} / \mathrm{R}$ is complex inflammatory process in which inflammatory cytokines such as ICAM-1, IL1 $\beta$ and TNF- $\alpha$ play crucial role (Beckman et al. 1990). Therefore, reduction of inflammatory reaction may be potential mechanisms of renoprotective effect of Ipre and sulforaphane against renal $\mathrm{I} / \mathrm{R}$ injury. The present study demonstrated that reduction of the expression of genes of inflammatory cytokines (ICAM-1, IL1 $\beta$ and TNF- $\alpha$ ) by sulforaphane and Ipre intervention, however the effect of sulforaphane was more pronounced than that of Ipre. We reported in a recent study by our group similar results for Ipre on inflammatory cytokines in renal I/R injury. Also, Zhao et al. (2010) reported reduction of myeloperoxidase activity (index for inflammatory process) in liver tissues exposed to I/R injury by sulforaphane treatment. Also, the present study demonstrated more attenuation in the expression of tested inflammatory cytokines by a combination of sulforaphane and Ipre than each one separately. These findings suggested synergistic action for sulforaphane and Ipre on reduction of inflammatory 
cytokines in renal I/R injury.

Finally, we examined the effect of sulforaphane and Ipre on expression of apoptotic marker (caspase-3) in kidney tissues. We found that giving either sulforaphane or Ipre alone caused significant attenuation of caspase- 3 expression. Unfortunately, addition sulforaphane to Ipre in a combination did not cause more attenuation in caspase- 3 expression than did each one alone. Moreover, sulforaphane did not confer more effect than Ipre did. Shokeir et al. (2012) reported attenuation of capase-3 expression by Ipre in renal $\mathrm{I} / \mathrm{R}$ and Negrette-Guzmán et al. (2013) reported reduction of caspase-9 (another executor of apoptosis) by sulforaphane in gentamycin induced nephrotoxicity. However, up to the best of our knowledge, no body investigated the effect of combination of them on apoptotic markers. Absence of synergistic effect for sulforaphane and Ipre on caspase-3 expression does not exclude this synergistic effect for the combination on apoptosis as this may be due to specific effect on caspase-3. This is considered as one of the limitations of this study as there was no actual assessment of apoptosis in kidney tissues and we relayed on assessment of the expression of caspase- 3 .

\section{Conclusions}

Both Ipre and sulforaphane protect kidney against $\mathrm{I} / \mathrm{R}$ injury through improvement of oxidative stress, enhancement of antioxidant genes such as Nrf2, HO-1 and NQO-1, reduction of inflammatory cytokines such as TNF-alpha, IL1b and ICAM-1 and apoptotic protein, caspase-3. There was a synergistic effect for both on induction of antioxidant genes and reduction of inflammatory cytokines but not on caspase- 3 and this synergistic effect is not reflected on kidney functions parameters.

\section{Conflict of Interest}

There is no conflict of interest.

\section{Acknowledgements}

This work was funded through the Science and Technology Development Fund (STDF), Egypt-grant no. 1140.

\section{References}

AMBROS JT, HERRERO-FRESNEDA I, BORAU OG, BOIRA JM: Ischemic preconditioning in solid organ transplantation: from experimental to clinics. Transpl Int 20: 219-229, 2007.

BANDAY AA, LOKHANDWALA MF: Transcription factor Nrf2 protects renal dopamine D1 receptor function during oxidative stress. Hypertension 62: 512-517, 2013.

BECKMAN JS, BECKMAN TW, CHEN J, MARSHALL PA, FREEMAN BA: Apparent hydroxyl radical production by peroxynitrite: implications for endothelial injury from nitric oxide and superoxide. Proc Natl Acad Sci USA 87: 1620-1624, 1990.

CARPENTER CB: Long-term failure of renal transplants: adding insult to injury. Kidney Int Suppl 50: S40-S44, 1995.

CHEN G, FANG Q, ZHANG J, ZHOU D, WANG Z: Role of the Nrf2-ARE pathway in early brain injury after experimental subarachnoid hemorrhage. J Neurosci Res 89: 515-523, 2011.

CUI W, BAI Y, MIAO X, LUO P, CHEN Q, TAN Y, RANE MJ, MIAO L, CAI L: Prevention of diabetic nephropathy by sulforaphane: possible role of Nrf2 upregulation and activation. Oxid Med Cell Longev 2012: 821936, 2012.

DUAN WR, GARNER DS, WILLIAMS SD, FUNCKES-SHIPPY CL, SPATH IS, BLOMME EA: Comparison of immunohistochemistry for activated caspase-3 and cleaved cytokeratin 18 with the TUNEL method for quantification of apoptosis in histological sections of PC-3 subcutaneous xenografts. J Pathol 199: 221-228, 2003.

HAYES JD, MCMAHON M: NRF2 and KEAP1 mutations: permanent activation of an adaptive response in cancer. Trends Biochem Sci 34: 176-188, 2009.

HERNANDEZ DJ, ROBERTS WB, MILES-THOMAS J, MAGHELI A, SAHA S, SCHAEFFER EM, RACUSEN LC, ALLAF ME: Can ischemic preconditioning ameliorate renal ischemia-reperfusion injury in a single-kidney porcine model? J Endourol 22: 2531-2536, 2008.

HONG F, FREEMAN ML, LIEBLER DC: Identification of sensor cysteines in human Keap1 modified by the cancer chemopreventive agent sulforaphane. Chem Res Toxicol 18: 1917-1926, 2005. 
HU R, XU C, SHEN G, JAIN MR, KHOR TO, GOPALKRISHNAN A, LIN W, REDDY B, CHAN JY, KONG AN: Gene expression profiles induced by cancer chemopreventive isothiocyanate sulforaphane in the liver of C57BL/6J mice and C57BL/6J/Nrf2 (-/-) mice. Cancer Lett 243: 170-192, 2006.

LEE JM, JOHNSON JA: An important role of Nrf2-ARE pathway in the cellular defense mechanism. J Biochem Mol Biol 37: 139-143, 2004.

LEWIS KN, MELE J, HAYES JD, BUFFENSTEIN R: Nrf2, a guardian of healthspan and gatekeeper of species longevity. Integr Comp Biol 50: 829-843, 2010.

LIVAK KJ, SCHMITTGEN TD: Analysis of relative gene expression data using real-time quantitative PCR and the 2(-Delta Delta C(T)) method. Methods 25: 402-408, 2001.

MOI P, CHAN K, ASUNIS I, CAO A, KAN YW: Isolation of NF-E2-related factor 2 (Nrf2), a NF-E2-like basic leucine zipper transcriptional activator that binds to the tandem NF-E2/AP1 repeat of the beta-globin locus control region. Proc Natl Acad Sci USA 91: 9926-9930, 1994.

NEGRETTE-GUZMÁN M, HUERTA-YEPEZ S, MEDINA-CAMPOS ON, ZATARAIN-BARRÓN ZL, HERNÁNDEZ-PANDO R, TORRES I, TAPIA E, PEDRAZA-CHAVERRI J: Sulforaphane attenuates gentamicin-induced nephrotoxicity: role of mitochondrial protection. Evid Based Complement Alternat Med 2013: 135314, 2013.

NITURE SK, KASPAR JW, SHEN J, JAISWAL AK: Nrf2 signaling and cell survival. Toxicol Appl Pharmacol 244: 37-42, 2010.

PING Z, LIU W, KANG Z, CAI J, WANG Q, CHENG N, WANG S, WANG S, ZHANG JH, SUN X: Sulforaphane protects brains against hypoxic-ischemic injury through induction of Nrf2-dependent phase 2 enzyme. Brain Res 1343: 178-185, 2010.

PIRSCH JD, GANE S, D'ALESSANDRO AM, PLEOG RJ, KNECHTLE SJ, SOLLINGER HW, KALAYOGLU M, BELZER FO: Determinants of graft survival after renal transplantation. Transplantation 61: 1581-1586, 1996.

SAITO M, MIYAGAWA I: Real-time monitoring of nitric oxide in ischaemia-reperfusion injury rat kidney. Urol Res 28: 141-146, 2000.

SHOKEIR AA, HUSSEIN AM, AWADALLA A, SAMY A, ABDELAZIZ A, KHATER S, BARAKAT N: Protection against renal ischemia/reperfusion injury: a comparative experimental study of the impact of ischemic preconditioning versus postconditioning. Arab J Urol 10: 418-424, 2012.

SHOKEIR AA, HUSSEIN AM, BARAKAT N, ABDELAZIZ A, ELGARBA M, AWADALLA A: Activation of nuclear factor erythroid 2-related factor (Nrf2) and Nrf-2-dependent genes by ischemic pre-conditioning and post-conditioning: new adaptive endogenous protective responses against renal ischemia/reperfusion injury. Acta Physiol 210: 342-353, 2014.

SILVA-ISLAS C, SANTANA RA, COLIN-GONZALEZ AL, MALDONADO PD: Nrf2 activation, an innovative therapeutic alternative in cerebral ischemia. In: Advances in the Preclinical Study of Ischemic Stroke. BALESTINO M (ed.), InTech, Rijeka, Croatia, 2012, pp 347-378.

SURH YJ, KUNDU JK, NA HK: Nrf2 as a master redox switch in turning on the cellular signaling involved in the induction of cytoprotective genes by some chemopreventive phytochemicals. Planta Med 74: 1526-1539, 2008.

TIMSIT MO, GADET R, BEN ABDENNEBI H, CODAS R, PETRUZZO P, BADET L: Renal ischemic preconditioning improves recovery of kidney function and decreases alpha-smooth muscle actin expression in a rat model. J Urol 180: 388-391, 2008.

VENUGOPAL R, JAISWAL AK: Nrf2 and Nrf1 in association with Jun proteins regulate antioxidant response element-mediated expression and coordinated induction of genes encoding detoxifying enzymes. Oncogene 17: 3145-3156, 1998.

WEIGHT SC, WALLER JR, BRADLEY V, WHITING PH, NICHOLSON ML: Interaction of eicosanoids and nitric oxide in renal reperfusion injury. Transplantation 72: 614-619, 2001.

YOON HY, KANG NI, LEE HK, JANG KY, PARK JW, PARK BH: Sulforaphane protects kidneys against ischemiareperfusion injury through induction of the Nrf2-dependent phase 2 enzyme. Biochem Pharmacol 75: 22142223, 2008. 
ZHAO HD, ZHANG F, SHEN G, LI Y-B, LI Y-H, JING H-R, MA L-F, YAO J-H, TIAN X-F: Sulforaphane protects liver injury induced by intestinal ischemia reperfusion through Nrf2-ARE pathway. World J Gastroenterol 16: 3002-3010, 2010.

ZHAO J, KOBORI N, ARONOWSKI J, DASH PK: Sulforaphane reduces infarct volume following focal cerebral ischemia in rodents. Neurosci Lett 393: 108-112, 2006.

ZHENG H, WHITMAN SA, WU W, WONDRAK GT, WONG PK, FANG D, ZHANG DD: Therapeutic potential of Nrf2 activators in streptozotocin-induced diabetic nephropathy. Diabetes 60: 3055-3066, 2011.

ZHU H, JIA Z, STROBL JS, EHRICH M, MISRA HP, LI Y: Potent induction of total cellular and mitochondrial antioxidants and phase 2 enzymes by cruciferous sulforaphane in rat aortic smooth muscle cells: cytoprotection against oxidative and electrophilic stress. Cardiovasc Toxicol 8: 115-125, 2008. 